Univerzitet u Beogradu
Poljoprivredni fakultet
Institut za poljoprivrednu tehniku
Naučni časopis
POLJOPRIVREDNA TEHNIKA
Godina XLV
Broj 3, 2020.
Strane: $15-26$

\title{
DEVELOPMENT OF A MULTI-ROLLER ABRASIVE CASSAVA PEELING MACHINE
}

\author{
Edeh, John C. ${ }^{* 1}$ \\ Michael Okpara University of Agriculture, Umudike, Abia State Nigeria
}

\begin{abstract}
A simple to operate, maintain and affordable multi-roller abrasive cassava peeling machine comprising a feed section, peeling chamber, abrasive surface, tuber discharge chute and waste peel chute was designed, fabricated and evaluated. The machine development was based on engineering standards and specification while considering crop, machine and operational factors to include the physical and mechanical properties of cassava tubers, abrasive property of peeling surface, material and speed of the machine. The machine was evaluated for performance with commonly used varieties NR 8082, 8083, 8208, 09/0581 and UMUCAS 38 having moisture content of $63.33 \%, 64.50 \%, 65.40 \%, 63.50 \%$ and $84.33 \%$ respectively. The performance evaluation results at a roller speed of 360rpm showed peeling efficiency of $91 \%$, throughput capacity of $2.17 \mathrm{~kg} / \mathrm{min}$, and a proportion by weight of peel of $0.9 \%$. The cassava peeling machine fabricated, eliminated the drudgery, loss of time and tuber flesh encountered in manual peeling with better product quality when compared with the existing machines.
\end{abstract}

Key words: Cassava variety, peeling machine, multi-roller abrasive, performance evaluation, peeling efficiency.

\section{INTRODUCTION}

Cassava (Manihot esculenta crantz) is a tuberous starchy root crop of the family Euphorbiaceae [1]. It is a popular crop grown worldwide and it's known for its large deposits of carbohydrates, drought tolerance and thriving well on marginal soil.

*Corresponding Author. E-mail: engredehjohnc@gmail.com 
There is an ever increasing demand globally for the different products of cassava such as chips, pellets, starch, garri, fufu, etc of which peeling of the tubers is necessary.

Peeling is the first and a critical unit operation performed after the cassava tubers have been harvested owing to its role in the detoxification of the tubers [2].

The high demand for cassava globally as constituent of human food, and as source of foreign exchange for producing countries calls for the total mechanisation of its processes.

Cassava processing thus deserves a serious attention so as to meet the needs of the local and international community. Several unit operations of in cassava processing including; grating, boiling/parboiling, drying, milling, sieving, toasting and extrusion has been successfully mechanised [3] while peeling has remained a bottleneck globally for the design engineer. Different efforts in this field have resulted to the production of several prototypes characterised by low efficiency and low quality performance.

Several mechanism and methods in cassava peeling has been adopted. These include; steam, manual, chemical and mechanical methods with its advantages and disadvantages. Some of the efforts in the mechanical field includes; a spring loaded cassava peeling machine by [4] with efficiency of $98.8 \%$ and a $15 \%$ broken tubers; the PRODA model of cassava peeling machine made with peeling balls recorded peeling efficiency 0of 30\% and much loss of the root flesh; UNN model of a batch cassava peeling made with abrasive materials loaded in a peeling drum resulted in a throughput capacity of $180 \mathrm{~kg} / \mathrm{hr}$ and loss of cassava tuber flesh; UNIBEN model of a cassava peeler designed at the mechanical engineering department of the University of Benin with a single tool point and fed tuber after tuber to its chuck recorded a peeling efficiency of about 25\%; Cassava peeler designed and fabricated at Tamil Nudu Agricultural university, Alade (2005) revealed that the throughput capacity, peeling efficiency and peel retention were found to be $549 \mathrm{~kg} / \mathrm{hr}, 50.33 \%$ and 0.572 respectively.

In a research carried out by [5], it was discovered that the most cassava farmers/growers are small farm holders between 0.5-5 ha. As a result of this, there is need for a portable and affordable peeling machine for the cottage industries to meet their processing needs. A multi-roller abrasive cassava peeling machine was developed at the Mechanical Engineering Department, Michael Okpara University of Agriculture, Umudike, Nigeria. The purpose of this work included the following; to develop a design data base for the peeling machine; form a relationship between the cassava tubers, machine and machine operational parameters; and also to establish machine operational parameters for effective peeling of the different sizes and shapes of cassava tubers.

\section{MATERIALS AND METHOD}

\section{Design Consideration}

The machine was designed based on the following considerations so as to obtain high efficiency, portability and reliability.

1. The capacity should be higher compared to manual operation.

2. Flexibility of the parts and components of the machine and convenient servicing.

3. Ability of the machine to peel tubers of different sizes, shapes and varieties.

4. Reliability, durability and rigidity of the materials for the machine components.

5. Cost and availability of the materials. 
6. Reduce loss of time and drudgery encountered in manual method.

7. Arrangement of the transmission components so as to transmit efficient power.

\section{Machine Component Description:}

The machine comprises of the following components; electric motor and gearbox, sprocket and chain drive, shafts, bearing, feed section, peeled tuber discharge chute, waste peel discharge chute, peeling rollers with abrasive surface made of emery cloth, support frame. Each of the components mentioned has one or more functions it must perform for the efficient performance of the cassava peeling machine and they include;

Electric Motor and Gearbox: The electric motor functions as the driver that powers the peeling machine while the gearbox serves as a speed reducer. The electric motor generates mechanical energy in the form of rotary motion which is transmitted using the sprockets and chain drive system.

Chain Drive and Sprocket: The sprockets and chain drive transmits the mechanical energy from the shaft of the electric motor and gearbox to the shafts of the peeling machines.

Shafts: The shafts of the cassava peeling machine transmits the mechanical energy that was generated from the electric motor and gearbox through the sprockets and chain drive system to the set of peeling rollers that uses the mechanical energy together with its abrasive surfaces to peel the cassava tubers.

Bearings: A bearing is a mechanical device that supports the shaft and reduces energy loss due to friction by eliminating friction in rubbing surfaces of the shafts and bulb.

Feed Section: This section of the machine serves as a portal through which the cassava tubers are introduced to the peeling chamber where the tubers undergo peeling action from the set of rollers that gets their action from the shaft rotation.

Peeled Tuber Discharge Chute: It is a discharge section through which the peeled tubers are collected after peeling. It can be easily assembled and disassembled from the machine.

Waste Peel Discharge Chute: This is a slanted casing through which the waste peel is let out of the peeling chamber. It is located below the peeling chamber.

Peeling Rollers and Abrasive Surface: The peeling rollers take the mechanical energy from the chain drive to peel the tubers. It is covered with emery cloth as an abrasive surface. The rotational motion of the rollers with its abrasive surface effects the peeling of the cassava tubers.

Support Frame: This holds the components of the cassava peeling machine. It serves as a shield withstanding torsional and vibrational forces occasioned by the operation of the machine. 


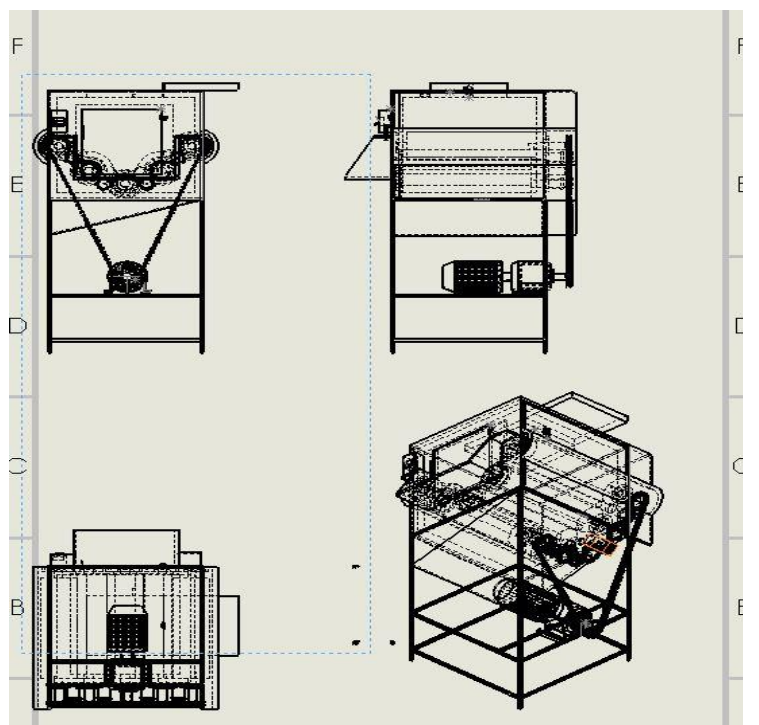

Figure 1: Orthographic View of the machine.

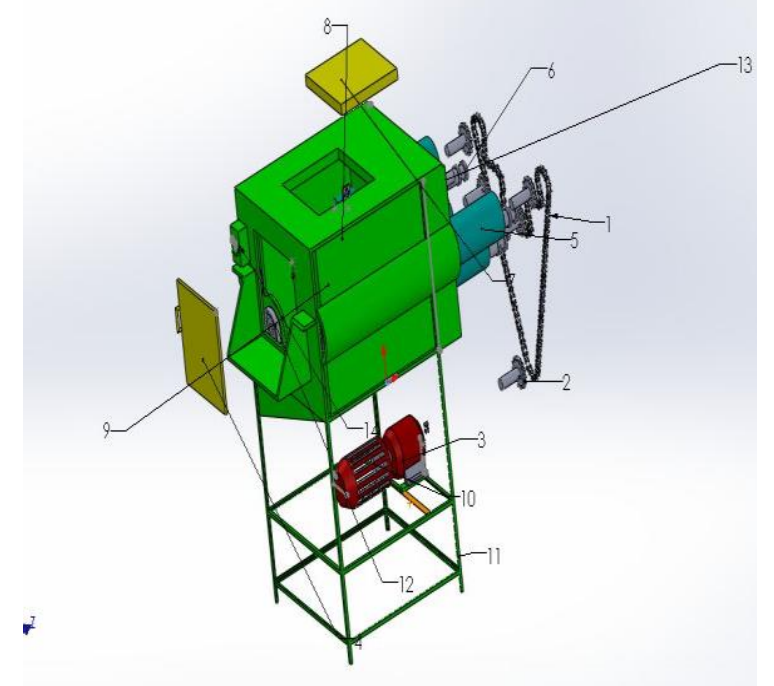

Figure 2: Isometric view of the multi-roller cassava peeling machine. Legend: 1.Chain; 2. Driver Sprocket; 3.Gearbox; 4.Outlet Chute opener; 5.Abrasive surface (Emery Cloth); 6. Idler Sprocket; 7.Feed section opener; 8.Peeling chamber; 9.Peeling Chamber; 10.Electric motor; 11.Main Fram; 12.Peeling Rollers; 13.Peeling roller driven sprocket; 14.Electric switch. 


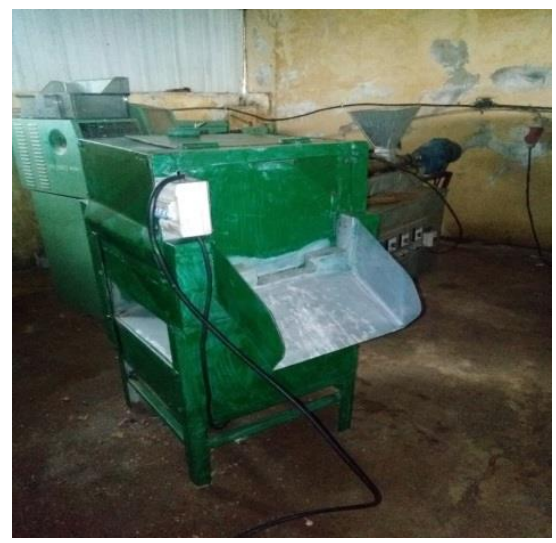

Plate 1: Pictorial view of the constructed multi-roller cassava peeling machine.

\section{Component Design/Fabrication}

\section{Chain Drive}

The transmission of the rotational motion of the electric motor to effect the needed revolutions of the peeling rollers was achieved by the use of chain drive. The parameters of the shaft of the electric motor and its sprocket were selected. Electric motor speed, $\mathrm{N}$ $=1440 \mathrm{rpm}$; number of teeth of the electric motor shaft, $\mathrm{T}_{1}=15$; desired number of teeth on peeling rollers sprockets, $\mathrm{T}_{2}=\mathrm{T}_{3}=\mathrm{T}_{4}=\mathrm{T}_{5}=\mathrm{T}_{6}=15$.

To achieve the desired speed of the peeling rollers, an integral gearbox of transmission ration 4:1 was integrated with the electric motor.

The Design power $\mathrm{P}_{\mathrm{D}}$, of the chain drive was determined as given by [6];

$$
P_{D}=P_{R} \times S_{F}
$$

Where; $P_{R}=$ rated power of motor,

$$
\mathrm{S}_{\mathrm{F}}=\mathrm{S}_{1} \times \mathrm{S}_{2} \times \mathrm{S}_{3}
$$

Service factor $S_{1}, S_{2}, S_{3}$ for constant loading, periodic lubrication and continuous service respectively [6]; [7]; [8].

For a complex chain drive involving five (5) driven sprockets of the peeling rollers and the sprocket of the electric motor-gearbox, he entire legth of chain was sectioned into five (5) sections $\mathrm{L}_{1}, \mathrm{~L}_{2}, \mathrm{~L}_{3}, \mathrm{~L}_{4}$, and $\mathrm{L}_{5}$.

First section is formed by the driving sprocket and the first (lowest) driven sprocket with centre to centre distance $x_{1}=300 \mathrm{~mm}$ while the sections connecting the driven sprockets have centre to centre distances of $\mathrm{x}_{2}, \mathrm{x}_{3}, \mathrm{x}_{4}, \mathrm{x}_{5}=130 \mathrm{~mm}$. 
To transmit the design power as calculated above, a chain type no 10 with two stands, pitch $\mathrm{p}$, roller diameter $\mathrm{d}$, minimum with of roller $\mathrm{w}$, of $15.875 \mathrm{~mm}, 10.16 \mathrm{~mm}$, and $9.65 \mathrm{~mm}$ (Table 21.1 and Table 21.4 of [6] respectively can be used.

The length of the chain as sectioned was determined with the formula suggested by [6] and [8]);

Where;

$$
\begin{aligned}
& \mathrm{L}_{1}=\mathrm{K}_{1} \times \mathrm{p} \\
& \mathrm{L}_{2}=\mathrm{K}_{2} \times \mathrm{p}
\end{aligned}
$$

$\mathrm{K}_{1}=$ chain link formed by the driver sprocket and the first driven sprocket.

$$
=\frac{T_{1}+T_{2}}{2}+\frac{2 x_{1}}{p}+\left(\frac{T_{2}-T_{1}}{2 \pi}\right)^{2} \times \frac{p}{x_{1}} \quad[6]
$$

$\mathrm{X}_{1=}$ centre distance of the first chain section.

$\mathrm{K}_{2}=\frac{T_{2}+T_{3}}{2}+\frac{2 x_{2}}{p}+\left(\frac{T_{3}-T_{2}}{2 \pi}\right)^{2} x \frac{p}{x_{2}}[6]$

$\mathrm{x}_{2}=\mathrm{x}_{3}=\mathrm{x}_{4}=\mathrm{x}_{5}=$ centre distance of the driven sprockets

$\mathrm{K}_{2}, \mathrm{~K}_{3}, \mathrm{~K}_{4}, \mathrm{~K}_{5}=$ chain link between the driven sprockets.

$\mathrm{L}_{2}=\mathrm{L}_{3}=\mathrm{L}_{4}=\mathrm{L}_{5}$

While the entire length $\mathrm{L}$, of the chain was gotten as

$$
\mathrm{L}=\mathrm{L}_{1}+4 \mathrm{~L}_{2}
$$

\section{Average Speed of the Chain}

The pitch circle diameter, $d_{1}$ and average speed of the chain which is the chain pitch line velocity, $\mathrm{V}$ on the sprockets were determined as $76.36 \mathrm{~mm} 14.39 \mathrm{~m} / \mathrm{s}$ using equations 7 and 8 as given by [6] and [8].

$$
\begin{aligned}
& \mathrm{d}_{1}=\mathrm{p} \times \operatorname{cosec} \times\left(\frac{180}{T}\right) \\
& \mathrm{V}=\frac{\pi x d_{1 \times N}}{60}
\end{aligned}
$$

Where; $\mathrm{T}=$ number of teeth of the sprockets, 15

$$
\mathrm{N}=\text { speed of the sprockets, } 360 \mathrm{rpm}
$$

\section{Angle of Articulation}

The angle of articulation, $\theta / 2$ through which the links swings as it enters contacts with the sprockets teeth was determined as $12^{0}$ using equation 9 by [6] and [8]);

$$
\theta=\frac{360}{T}
$$

\subsubsection{Selection of Drive Shafts}

The shaft diameters, $\mathrm{D}$ of the peeling rollers of this machine were determined using maximum stress relations given by [7]; [8] and [6] in equation 10 as;

$$
\mathrm{D}=\left[\frac{16}{\pi \tau}\left(\sqrt{\left(K_{b} M_{b}\right)^{2}+\left(K_{t} M_{t}\right)^{2}}\right)\right]^{\frac{1}{3}}
$$


Where;

$\tau=$ Allowable shear stress for steel shaft with provision for key ways, $(42 \mathrm{~N} / \mathrm{mm})$

$\mathrm{M}_{\mathrm{t}}=$ Maximum Twisting Moment on the shafts, $\mathrm{N}-\mathrm{mm}$

$\mathrm{M}_{\mathrm{b}}=$ Maximum Bending Moment on the shafts, $\mathrm{N}-\mathrm{mm}$

$\mathrm{K}_{\mathrm{b}}=$ Combined shock and fatigue factor for bending, 2

$\mathrm{K}_{\mathrm{t}}=$ Combined shock fatigue factor for twisting, 1.5

\section{Selection of Prime Mover}

The power, $\mathrm{p}$ required for the operation of this machine is the power required to drive the shaft of the speed reducer which then drive the shaft on the peeling rollers. The power in watts required to drive this machine was determined as $1.474 \mathrm{HP}(1.100 \mathrm{kw})$ using equation 12 .

$$
\mathrm{P}=\frac{2 \pi N T}{60}
$$

Where; $\quad \mathrm{P}=$ Power to drive the machine in watts

$\mathrm{N}=$ Output speed of the speed reducer and peeling rollers

$\mathrm{T}=$ Twisting moment on the output shaft of the speed reducer, $29.58 \mathrm{~N}-\mathrm{m}$

Taking care of $10 \%$ possible loss due to friction [9], the power required to drive the multi-roller abrasive peeling machine was computed from equation $111.100 \mathrm{Kw}(1.474$ HP). Therefore, (2HP) electric motor which can be powered using a 3 phase electric power supply was selected for this cassava peeling machine.

\section{Machine Operation}

The machine was evaluated for performance in terms of throughput capacity, $\mathrm{T}_{\mathrm{C}}$, proportion of weight of peel, $\mathrm{P}$, and peeling efficiency $\mu$. The throughput was measured in terms of mass of tubers per batch of peel per unit time.

The peeling chamber was filled with different batch sizes of $5 \mathrm{~kg}, 10 \mathrm{~kg}, 15 \mathrm{~kg}$, and $20 \mathrm{~kg}$ of different varieties of cassava (NR 8082, 8083, 8208, 09/0581 and UMUCAS 38). The time of peel, mass of peeled tuber, mass of waste peel were duly noted during the test. The throughput capacity, $\mathrm{T}_{\mathrm{C}}$, proportion of weight of peel, $\mathrm{P}$, and peeling efficiency $\mu$, were gotten from the expression given by [10];

$$
\begin{aligned}
& \mathrm{T}_{\mathrm{C}}=\frac{M_{C}}{T} \\
& \mathrm{P}=\frac{M_{P C}}{M_{S}} \\
& \mu=\frac{M_{P C}}{M_{P R}+M_{P C}} \text { (Aggarwal, 1987) }
\end{aligned}
$$




\section{RESULTS AND DISCUSSION}

Table 1: The machine design technical parameters

\begin{tabular}{lccc}
\hline & & & \\
Technical/Calculated Parameters & Symbol & Value & Unit \\
\hline Chain Length & $L$ & 2.8 & $\mathrm{~m}$ \\
Angle of Articulation & $\theta / 2$ & $12^{0}$ & Radians \\
Design power of the chain & $P_{D}$ & 2.475 & $\mathrm{~kW}$ \\
Average Speed of chain & $V$ & 14.39 & $\mathrm{~m} / \mathrm{s}$ \\
Power required & $P$ & 2 & $\mathrm{Hp}$ \\
Shaft speed & $N_{2}$ & 360 & $\mathrm{rpm}$ \\
Diameter of peeling roller shafts & $\mathrm{D}$ & 0.46 & $\mathrm{~m}$ \\
Maximum mass of cassava tubers per batch of peel & $M$ & 24 & $\mathrm{~kg}$ \\
Maximum bending moment on the peeling roller shafts & $M_{b}$ & $1.61,0.89,0.23$ & $\mathrm{Nm}$ \\
Effective volume of peeling chamber & $V_{P C}$ & 0.072 & $\mathrm{~m}^{3}$ \\
\hline
\end{tabular}

Table 2. Varieties and parameters for performance evaluation

\begin{tabular}{|c|c|c|c|c|c|c|c|}
\hline Type & $\begin{array}{c}\text { Time } \\
\text { of } \\
\text { peel, } \\
T \\
(\mathrm{~min}) \\
\end{array}$ & $\begin{array}{l}\text { Weight } \\
\text { of tuber } \\
\text { before } \\
\text { peeling } \\
M s(\mathrm{~kg})\end{array}$ & $\begin{array}{c}\text { Weight of } \\
\text { completely } \\
\text { peeled tuber } \\
\text { Mc }(\mathrm{kg})\end{array}$ & $\begin{array}{c}\text { Mass } \\
\text { of peel } \\
M p(k g)\end{array}$ & $\begin{array}{l}\text { Weight of } \\
\text { peeled } \\
\text { tuber } \\
\text { Mpc }(k g)\end{array}$ & $\begin{array}{l}\text { Weight of } \\
\text { peel } \\
\text { removed } \\
\text { by hand } \\
\text { Mpr }\end{array}$ & $\begin{array}{c}\text { Tuber } \\
\text { loss } \\
M_{F} \\
(\mathrm{~kg})\end{array}$ \\
\hline$N R$ & 2 & 5 & 1.20 & 0.6 & 4.35 & 0.60 & 0.05 \\
\hline \multirow[t]{3}{*}{8082} & 4.01 & 10 & 3.99 & 1.29 & 8.50 & 1.29 & 0.21 \\
\hline & 7.32 & 15 & 4.94 & 1.58 & 13.16 & 1.58 & 0.26 \\
\hline & 10.10 & 20 & 7.44 & 2.59 & 17.10 & 2.59 & 0.31 \\
\hline$N R$ & 1.98 & 5 & 1.2 & 0.82 & 4.10 & 0.82 & 0.08 \\
\hline 09/058 & 3.92 & 10 & 3.42 & 1.62 & 8.20 & 1.62 & 0.18 \\
\hline \multirow[t]{2}{*}{1} & 7.25 & 15 & 3.44 & 1.98 & 12.80 & 1.98 & 0.22 \\
\hline & 10.00 & 20 & 6.96 & 2.21 & 17.50 & 2.21 & 0.29 \\
\hline$U M U C$ & 2.10 & 5 & 1.71 & 0.70 & 4.21 & 0.70 & 0.09 \\
\hline \multirow[t]{3}{*}{ AS 38} & 4.12 & 10 & 2.82 & 0.82 & 9.00 & 0.82 & 0.18 \\
\hline & 7.10 & 15 & 5.28 & 1.63 & 13.15 & 1.63 & 0.22 \\
\hline & 9.53 & 20 & 3.85 & 2.35 & 17.36 & 2.35 & 0.29 \\
\hline$N R$ & 2.01 & 5 & 1.28 & 0.60 & 4.34 & 0.60 & 0.60 \\
\hline \multirow[t]{3}{*}{8083} & 3.96 & 10 & 4,01 & 1.30 & 8.49 & 1.30 & 0.21 \\
\hline & 7.28 & 15 & 4.86 & 1.57 & 13.12 & 1.57 & 0.31 \\
\hline & 10.04 & 20 & 7.35 & 2.58 & 17.00 & 2.58 & 0.42 \\
\hline$N R$ & 2.05 & 5 & 1.21 & 0.86 & 4.02 & 0.86 & 0.12 \\
\hline \multirow[t]{3}{*}{8082} & 4.02 & 10 & 3.56 & 1.57 & 8.22 & 1.57 & 0.21 \\
\hline & 7.94 & 15 & 3.87 & 1.80 & 12.74 & 1.80 & 0.41 \\
\hline & 9.92 & 20 & 6.92 & 2.17 & 17.46 & 2.17 & 0.37 \\
\hline
\end{tabular}


Table 3. Performance evaluation result of the multi-roller cassava peeling machine

\begin{tabular}{cccccccc}
\hline Type & Ms & $\begin{array}{c}\text { Prop. } \\
\text { by weight } \\
P \\
(k g)\end{array}$ & $\begin{array}{c}\text { Peeling } \\
\text { effic. } \\
(\mu)\end{array}$ & $\begin{array}{c}\text { Mech. } \\
\text { damage } \\
(\lambda)\end{array}$ & $\begin{array}{c}\text { Peel } \\
\text { retention } \\
(P R)\end{array}$ & $\begin{array}{c}\text { Quality } \\
\text { perform. } \\
\text { efficienc } \\
(\Omega)\end{array}$ & $\begin{array}{c}\text { Throughput } \\
\text { Capacity } \\
\text { Tc }(\text { min })\end{array}$ \\
\hline NR & 5 & 0.87 & 0.87 & 0.04 & 0.03 & 0.96 & 2.17 \\
8082 & 10 & 0.85 & 0.86 & 0.05 & 0.04 & 0.95 & 2.11 \\
& 15 & 0.87 & 0.89 & 0.05 & 0.05 & 0.95 & 1.79 \\
& 20 & 0.85 & 0.86 & 0.04 & 0.03 & 0.96 & 1.69 \\
NR & 5 & 0.82 & 0.83 & 0.06 & 0.04 & 0.93 & 2.07 \\
$09 / 0581$ & 10 & 0.82 & 0.83 & 0.05 & 0.04 & 0.95 & 2.09 \\
& 15 & 0.85 & 0.86 & 0.06 & 0.05 & 0.93 & 1.76 \\
& 20 & 0.87 & 0.88 & 0.04 & 0.03 & 0.96 & 1.75 \\
UMUCA & 5 & 0.84 & 0.85 & 0.05 & 0.04 & 0.95 & 2.00 \\
S38 & 10 & 0.90 & 0.91 & 0.06 & 0.05 & 0.94 & 2.18 \\
& 15 & 0.87 & 0.88 & 0.04 & 0.03 & 0.96 & 1.80 \\
$N R$ & 20 & 0.86 & 0.88 & 0.07 & 0.06 & 0.92 & 1.82 \\
8083 & 5 & 0.86 & 0.87 & 0.04 & 0.03 & 0.95 & 2.15 \\
& 10 & 0.84 & 0.86 & 0.04 & 0.03 & 0.95 & 2.14 \\
& 15 & 0.87 & 0.89 & 0.05 & 0.04 & 0.94 & 1.80 \\
$N R$ & 5 & 0.85 & 0.86 & 0.05 & 0.04 & 0.94 & 1.69 \\
8082 & 10 & 0.80 & 0.82 & 0.09 & 0.07 & 0.90 & 1.96 \\
& 15 & 0.82 & 0.83 & 0.05 & 0.04 & 0.94 & 2.04 \\
& 20 & 0.87 & 0.87 & 0.09 & 0.07 & 0.90 & 1.60 \\
& & & 0.88 & 0.05 & 0.04 & 0.94 & 1.76 \\
\hline
\end{tabular}

Table 4. Bill of engineering measurement and evaluation (BEME)

\begin{tabular}{|c|c|c|c|c|c|}
\hline$S / N$ & Component part & Material used & Qty & Rate & $\operatorname{Amount}(\mathrm{A})$ \\
\hline 1 & Electric motor & 2 HP 3-phase & 1 & - & 40000 \\
\hline \multirow[t]{2}{*}{2} & Frame & $\begin{array}{l}\text { Mild steel angle iron } \\
2 \times 2\end{array}$ & 3 & 2500 & 7500 \\
\hline & & $\begin{array}{l}\text { Mild steel angle iron } \\
1 \times 1\end{array}$ & 2 & 1000 & 2000 \\
\hline 3 & Bearing & Mild steel & 10 & 800 & 8000 \\
\hline 4 & Bolts and nuts & Mild steel & 16 & 80 & 1280 \\
\hline \multirow[t]{2}{*}{5} & Plate & Mild steel $2 \mathrm{~mm}$ & 1 & - & 15200 \\
\hline & & Mild steel $10 \mathrm{~mm}$ & 1 & - & 30000 \\
\hline 6 & hinges & Mild steel & 2 & 150 & 300 \\
\hline 7 & Pulley & Mild steel & 4 & 900 & 3600 \\
\hline 8 & Sprockets & Carbonised mild steel & 6 & 1500 & 9000 \\
\hline 9 & Rollers & Hardened mild steel & 5 & 6520 & 32600 \\
\hline 10 & Shaft & Hardened mild steel & 5 & 2530 & 12650 \\
\hline 11 & Chain & Medium carbon & 1 & 5200 & 5200 \\
\hline 12 & Paint & Red oxide, green & - & - & 11000 \\
\hline 13 & Transportation & - & - & - & 15000 \\
\hline 14 & Labour & - & - & - & 60000 \\
\hline \multirow[t]{2}{*}{15} & Miscellaneous & - & - & - & 29320 \\
\hline & Total & - & - & - & 282650 \\
\hline
\end{tabular}


Results of this research work are presented in Tables 1- 4. Table 1 reveals the machine design technical parameters.

According to the results, the power requirement of the machine is $1.464 \mathrm{~kW}$ which entails that $2 \mathrm{HP}$ electric motor with speed of $1440 \mathrm{rpm}$ will power the machine.

This power is transmitted to the shafts bearing the peeling rollers that peel the cassava tubers with an abrasive surface (emery cloth). The peeling rollers rotate at a speed of about $360 \mathrm{rpm}$.

Tables 2 and 3 present the machine performance results. From the results as recorded in these tables, it is observable that the machine attains peeling efficiency of up to $91 \%$ at minimum average flesh loss of $0.195 \mathrm{~kg}$ for Umucas 38 variety with highest moisture content.

This is an indication that moisture content favours the developed multi-roller abrasive peeling.

From the bill of engineering measurements and evaluation, as recorded in Table 4, the total cost of the fabrication of the machine is two hundred and eighty two thousand, six hundred and fifty naira only (N282,650.00).

\section{CONCLUSION}

The need for pre-operation such as cutting of the cassava tuber with depressed sections, tuber stumps, and washing of the tubers before peeling in order to have an effective operation poses a great limitation. However, an improvement can still be made so as to eliminate the time expended in preoperational activities. The Developed cassava peeler recorded high peeling efficiency of $91 \%$ and throughput of $2.71 \mathrm{~kg} / \mathrm{min}$ for variety having highest moisture content, hence revealing that the machine performs better with freshly harvested tubers (with high moisture content) The cassava peeler produced is a prototype therefore can only contain about $24 \mathrm{~kg}$ of cassava at a time. However it can be improved upon by scaling up the peeling chamber capacity for industrial purposes. To increase the capacity of the machine, the time taken to cut the depressed parts and shrubs should be eliminated. Further research could be carried out on the Production of a more advanced machine that will take care of the stump and depressed part.

\section{REFERENCES}

[1] Kochlar, S. L (1981), Tropical crops: A textbook of economic botany: Macmillan Publishers Ltd, pp. 467.

[2] Opara, L. U (1999). Yam storage. In CIGR Handbook of Agricultural Engineering Volume IV: Agro Processing. The American Society of Ag. Engineers, ST Joseph, MI. 182-214.

[3] Ezekwe, G. O (1976); "A feature for achieving a constant depth of peel in the mechanical peeling of cassava"; Nigeria Journal of Engineering, Volume 1, Issue 3, pp.174-181. 
[4] Adetan, D.A., Adekoya, L.O., Aluko, O.B. \& Makanjuola, G.A. (2005), ‘'An Experimental Mechanical Cassava Tuber Peeling Machine', Journal of Agricultural Engineering and Technology (JAET). 13, 27-34.

[5] Howeler, R. H; Watananouta, W; Tran Ngoc Ngoan (2004); "Farmers decide. A participatory approach to development and dissemination of improved cassava technology that improve yield and prevent soil degradation." Proceedings of $13^{\text {th }}$ International Society of Tropical Root Crops held in Arusha Tanzania.

[6] Khurmi, R. S and Gupta, J. K, 2012. A textbook of machine design. Published by S. Chand and Company.

[7] Bur, A. H; Cheathan, J. B (2002) Mechanical; Analysis and Design (2 ${ }^{\text {nd }}$ Edition) Prentice Hall Publishers, New Delhi.

[8] Sharma, P. C, Aggarwal D. K; A textbook of machine design. S. K Katara and Sons Publishers, New Delhi (2009).

[9] Nwankwojike, B. N. (2012). Angle of Repose of Digested Oil Palm Fruit Mash and Pulp on Steel. Int. Jour. of Innovative Technology \& Creative Eng.. Vol .2 No.2 pp 12 - 17.

[10] Olukunle, O.J and Akinnuli, B.O. (2012) "Performance Evaluation of a Single Action Cassava Peeling Machine" Federal University of Technology, Akure (FUTA).

\title{
RAZVOJ ABRAZIVNE MULTI ROLER MAŠINE ZA LJUŠTENJE CASSAVA KRTOLA
}

\section{Edeh, John C.}

\author{
Michael Okpara University of Agriculture, \\ Umudike, Abia State Nigeria
}

Sažetak. Dizajnirana, izrađena i ocenjena kao jednostavna za rukovanje, održavanje i pristupačna brusna mašina sa multi-valjcima za ljuštenje Cassava krtola (Manihot esculenta crantz), koja se sastoji od: prijemnog koša, komora za ljuštenje, abrazivne površine valjka, kanala za ispuštanje krtola i otpada. Razvoj mašine je zasnovan na inženjerskim standardima i specifikacijama uz razmatranje osobina Cassava krtole, mašine i radnih parametara koji uključuju fizička i mehanička svojstva Cassava krtola, abrazivnih osobina površine ljuštenja, materijala i brzine rotora mašine. Mašina ima procenjene performanse za uobičajeno korišćene Cassava varijetete: NR 8082, 8083, $8208,09 / 0581$ i UMUCAS 38 sa sadržajem vlage od $63,33 \%, 64,50 \%, 65,40 \%, 63,50 \%$ i $84,33 \%$ retrospektivno. Rezultati analize performansi mašine kod brzine valjka od 360 $\min ^{-1}$ pokazali su: efikasnost ljuštenja od $91 \%$, propusni kapacitet od $2,17 \mathrm{~kg} / \mathrm{min}$, sa udelom težine kore od $0,9 \%$. Prikazna mašina za ljuštenje krtola kasave, eliminisala je gubitak vremena i mase krtole koji se pojavljuje kod ručnog ljuštenja krtola, sa boljim kvalitetom proizvoda u poređenju sa postojećim mašinama. 
Ključne reči: Cassava varijeteti, mašina za ljuštenje, abrazivni multi roler valjci, ocena performansi, efikasnost ljuštenja.

Prijavljen:

Submitted:

Ispravljen:

Revised:

Prihvaćen:

Accepted:
30.09.2019.

10.04.2020

20.05.2020 